\title{
ANALISIS PRODUKSI PADI ORGANIK DI KABUPATEN SRAGEN TAHUN 2008
}

\author{
Fajar Widayat Novianto ${ }^{1}$ \\ Eni Setyowati ${ }^{1}$ \\ ${ }^{1}$ Fakultas Ekonomi Universitas Muhammadiyah Surakarta \\ E-mail: nayla.azka@yahoo.com
}

\begin{abstract}
The purpose of this study was to analyze factors influencing the production of organic rice that is land area, seed, labor, fertilizer, and water. This study uses OLS analysis tool (ordinary least squares method). The results show a significant correlation between the variable land area (LH), number of seeds (BH), number of workers (TK), total fertilizer (KDP), and the cost of irrigation (AIR) with organic rice production. Among these five variables is negatively related to variable fertilizer. While the existence of the model test showed that the model exists for use. Land area ( $\mathrm{LH}$ ) has a positive influence on the production of organic rice. The number of seeds (BH) has a positive influence on the production of organic rice, Labor (TK) has a positive influence on the production of organic rice. The use of organic fertilizers (KDP) have an influence on the production of organic rice nagatif. The cost of irrigation (WATER) has a positive influence on the production of organic rice. The results of the classical model assumptions there is no problem, either multicollinearity, heteroscedasticity, specification model, and normality.
\end{abstract}

Key word: produksi, padi organik, ordinary least squares, intensifikasi

\section{PENDAHULUAN}

Sebagian besar para petani di Indonesia dapat digolongkan ke dalam peasant atau subsistence yaitu petani yang mempunyai lahan sempit (kurang dari 0,5 ha) dan memanfaatkannya untuk kebutuhannya sendiri. Ada dua faktor utama yang menjadi hambatan di dalam pengembangan usaha tani di Indonesia (1) Faktor biologi: seperti lahan pertanian dengan macam dan tingkat kesuburannya, bibit, varietas, pupuk, obat-obatan, gulma, dan lain sebainya. (2) Faktor sosial ekonomi: seperti biaya produksi, harga, tenaga kerja, pendidikan petani, tingkat pendapatan, resiko dan ketidakpastian, kelembagaan, tersedia- nya kredit, dan sebagainya.

Di samping itu permasalahan yang dihadapi sektor pertanian secara umum pada era industrialisasi nanti adalah adanya kenyataan terjadinya perpindahan tenaga kerja dari sektor pertanian ke sektor non pertanian. Hal ini disebabkan pertumbuhan industri yang lebih cepat membutuhkan tenaga kerja yang semakin banyak, sehingga tenaga kerja di sektor pertanian menjadi langka.

Pembangunan pertanian di provinsi Jawa Tengah mempunyai peran penting dikarenakan sampai saat ini provinsi Jawa Tengah masih merupakan provinsi penyandang pa- 
ngan nasional, sehingga produktivitas padi khususnya terus dipacu yang pada tahun 2000 produksi padi berhasil mencapai 50,77 kwintal setiap hektarnya. Sebagai salah satu daerah lumbung padi di provinsi Jawa Tengah, adalah kabupaten Demak pada tahun 2001 telah mencapai rata-rata 52,34kw/ha. Sedangkan kecamatan Karanganyar mempunyai rata-rata produksi yang paling tinggi 55,98kw/ha (Susilowati, 2004).

Tetapi produksi padi mengalami pelandaian (leveling off) selama lima tahun terakhir. Penyebab utama rendahnya produktivitas tanaman padi sawah adalah rendahnya pengisian biji atau masih tingginya gabah hampa 24,2-28,2 persen. Teknik budidaya yang masih dilakukan secara konvensional juga menjadi salah satu penyebab tanaman padi belum dapat mengekspresikan kemampuan genetiknya.

Pengujian 12 yang dilakukan pada musim kemarau pada tahun 1996 di Los Banos, Laguna dan di Philipphine Rice Research Institute (PhilRice), Munoz, Nueva Ecija, Philippine rata-rata spikelet fertile per malai hanya mencapai 75,8 persen.

Pengujian selanjutnya pada tahun 1998 dari 6 varietas yang dilepas IRRI, rata-rata jumlah spikelet fertile justru menurun yaitu hanya mencapai 71,8 persen dengan rata-rata jumlah spikelet per malai 131,5 spikelet. Berdasarkan informasi ini memberikan gambaran bahwa persentase spikelet fertile tidak sepenuhnya ditentukan oleh faktor genetiknya, melainkan juga faktor lingkungan (Sumardi $d k k, 2007)$.

Asumsi bahwa faktor lingkungan memiliki andil yang besar dalam menekan jumlah spikelet steril dibuktikan melalui penerapan metode System of Rice Intensification (SRI).
Metode SRI memuat dua hal pokok yaitu: (1) memerlukan tanaman sebagai makluk hidup yang memiliki fase-fase pertumbuhan yang harus difahami, (2) melakukan perbaikan teknologi budidaya Dengan menciptakan lingkungan tumbuh yang optimal untuk setiap fase pertumbuhan dan perkembangan tanaman. Aplikasi metode SRI pada sentra produksi padi di Philippina jumlah spikelet fertile mencapai 87 persen, jumlah spikelet permalai 345 , panjang malai $30,4 \mathrm{~cm}$.

Upaya yang dapat dilakukan untuk meningkatkan produktivitas tanaman padi antara lain melakukan manipulasi source dan sink tanaman. Upaya merubah hubungan sourcesink tanaman dapat dilakukan dengan perbaikan lingkungan tumbuh agar menjadi lebih optimal untuk pertumbuhan dan perkembangan tanaman, dengan mengoptimalisasikan sumberdaya alam yang tersedia. Pengelolaan ruang, cahaya, air dan nutrisi yang optimal tidak hanya meningkatkan efisiensi source, tetapi juga meningkatkan kekuatan sink.

Peningkatan source dilakukan Dengan meningkatkan jumlah anakan total, sehingga luas daun juga meningkat. Peningkatan kekuatan sink dilakukan dengan mengupayakan presentase anakan produktif di atas 80 persen, jumlah spikelet per malai, panjang malai dan persentase spikelet fertile (Sumardi dkk, 2007).

Intensifikasi terbukti dapat meningkatkan produksi padi di Indonesia sampai dengan tahun 1984. Masukan produksi dalam pertanian modern ialah varietas unggul, pupuk buatan, terutama pupuk nitrogen $(\mathrm{N})$, seringkali diberikan dengan takaran tinggi tanpa disertai pemberian bahan organik sehingga dalam waktu lama mengakibatkan kerusakan kesehatan tanah. Hal tersebut men- 
jadikan penurunan produktivitas padi mulai tahun 1990-an.

Pemberian bahan organik mampu meningkatkan hasil gabah pada padi kering secara nyata. Dalam meningkatkan produksi padi perlu dilakukan pelestarian lingkungan produksi, termasuk mempertahankan kandungan bahan organik tanah dengan memanfaatkan jerami padi. Penambahan bahan organik merupakan suatu tindakan perbaikan lingkungan tumbuh tanaman yang antara lain dapat meningkatkan efisiensi pemupukan. Hasil penelitian penggunaan bahan organik, seperti sisa-sisa tanaman yang melapuk, kompos, pupuk kandang atau pupuk organik cair menunjukan bahwa pupuk organik dapat meningkatkan produktivitas tanah dan efisiensi pemupukan serta mengurangi kebutuhan pupuk terutama pupuk kandang.

Penggunaan jerami dengan takaran 2 ton juga menunjukan hasil yang lebih tinggi dibanding tanpa jerami pada berbagai perlakuan pemupukan. Pengembalian jerami atau seresah kedelai dalam bentuk segar maupun yang sudah dikomposkan secara nyata dapat meningkatkan serapan nitrogen tanaman padi baik pada musim hujan maupun musim kemarau, meskipun tidak berpengaruh terhadap hasil gabah. Pemberian jerami meningkatkan kandungan nitrogen tanah, dan mengurangi jumlah nitrogen pupuk yang diserap tanaman.

Pupuk organik dapat berasal dari pupuk kandang ayam, jerami padi, azolla, daun lamtoro, sekam padi, belotong, limbah agroindustri (seperti limbah pengolahan minyak sawit). Secara garis besar keuntungan yang diperoleh dari pemanfaatan pupuk organik adalah perbaikan (a) sifat fisik tanah, (b) sifat kimia tanah, (c) sifat biologi tanah, dan (d) kondisi sosial. Penggunaan pupuk organik juga mempunyai kelemahan, di antaranya ialah: (1) diperlukan dalam jumlah yang sangat banyak untuk memenuhi kebutuhan unsur hara dari suatu pertanaman. (2) hara yang dikandung untuk bahan yang sejenis sangat bervariasi, (3) bersifat ruah (bulky), baik dalam pengangkutan dan penggunaanya di lapangan, dan (4) kemungkinan akan menimbulkan kekahatan unsur hara apabila bahan organik yang diberikan belum cukup matang. Pemberian pupuk kandang dapat menyebabkan unsur hara $\mathrm{N}, \mathrm{P}$, dan $\mathrm{K}$ di dalam larutan tanah menjadi seimbang, sehingga dapat meningkatkan pertumbuhan vegetative tanaman.

Berdasarkan peranannya dalam menyediakan nutrisi dan memperbaiki sifat tanah maka penggunaan pupuk organik diharapkan dapat meningkatkan efisiensi pemupukan nitrogen, kinerja fisiologi, dan hasil tanaman padi sawah (Iqbal, 2008). Dari latar belakang tersebut maka penelitian ini membatasi pada permasalahan Apakah faktor variabel luas lahan, bibit padi, pupuk, air, tenaga kerja, berpengaruh terhadap produksi padi organik di kabupaten Sragen tahun 2008 dan faktor mana yang paling berpengaruh antara variabel luas lahan, bibit padi, pupuk, air, tenaga kerja, terhadap produksi padi organik di kabupaten Sragen tahun 2008. Tujuan penelitian ini adalah menganalisis faktor-faktor yang mempengaruhi produksi padi organik yaitu luas lahan, bibit padi, banyaknya pupuk, banyaknya biaya untuk pengairan, dan banyaknya tenaga kerja.

Permintaan terhadap beras sebagai makanan utama sebagian besar penduduk Indonesia mengalami peningkatan sebesar 2,23 persen per tahun, dan proyeksi permintaan beras pada tahun 2010 sekitar 41,50 juta ton. Selanjutnya dikatakan bahwa defisit beras 
akan meningkat sekitar 13,50 persen per tahun 12,78 juta ton pada tahun 2010 apabila tidak dilakukan peningkatan produktivitas dan perluasan areal panen. Defisit beras pada tahun 2003 diperkirakan sekitar 3.587.461 ton, dan kontribusi terbesar dalam memenuhi permintaan beras adalah melalui peningkatan produktivitas, yaitu 56,80 persen.

Peluang peningkatan produktivitas padi masih memungkinkan karena hingga saat ini rata-rata produktivitas yang dicapai di tingkat petani masih di bawah potensi hasil atau hasil penelitian. Adanya kesenjangan hasil tersebut mengindikasikan bahwa penerapan teknologi di tingkat petani masih belum optimal sesuai anjuran.

Berkaitan dengan hal tersebut, pemupukan merupakan salah satu cara yang terus dilakukan. Pemakaian pupuk anorganik secara intensif serta penggunaan bahan organik yang terabaikan untuk mengejar hasil yang tinggi menyebabkan bahan organik tanah menurun. Keadaan ini akan menurunkan produktivitas lahan. Dalam upaya untuk meningkatkan produktivitas lahan secara berkelanjutan diperlukan terobosan yang mengarah pada efisiensi usahatani dengan memanfaatkan sumberdaya lokal (Arafah, 2003).

Pemerintah Kabupaten Sragen mentargetkan daerahnya menjadi sentra produksi beras organik terbesar di Indonesia pada 2010. Daerah ini telah mengembangkan lahan padi organik seluas 1,973 hektar pada akhir 2004. Areal ini merupakan perluasan dari 232 hektar pada 2001. Jumlah kelompok tani dan petani organik juga melejit: dari 29 kelompok dengan 639 petani saat program dimulai 2001, menjadi 247 kelompok dengan 1.721 petani pada 2004. Alhasil, jumlah produksi padi organik pun ikut melonjak tajam. Jika pada 2001 dihasilkan 1.187 ton gabah kering giling, tiga tahun kemudian sudah hampir 11 ribu ton gabah kering giling. Bupati Sragen Untung Wiyono mengaku punya tiga alasan memilih padi organik sebagai kebijakan unggulan. Pertama, untuk melestarikan lingkungan hidup back to nature, karena padi organik hanya memakai pupuk dan pestisida organik. Kedua, alasan kesehatan back to healthy. Beras organik lebih sehat karena tak memakai pestisida kimia. Terakhir, alasan pasar (market oriented). Segmen beras organik adalah kalangan menengah ke atas, harga jualnya pun di atas beras nonorganik. Beras organik menthik wangi misalnya, di PD PAL dijual Rp.4.000 per kg dan di Padi Mulya Rp.5.000. Harga ini sudah terhitung murah. Sebab, harga beras organik impor dari Thailand Rp.19 ribu dan dari Jepang lebih mahal lagi Rp.70 ribu per kg. Harga gabah kering panen organik juga lebih tinggi Rp.100-200 per kg dibanding nonorganik. Di sisi lain biaya produksi padi organik juga lebih irit. Sebab, petani bisa memanfaatkan kotoran hewan, jerami padi, dan bahan alami lain, untuk bahan pupuk organik. Pestisida organik pun cukup dibuat dari daun mimba (Azadirachta indica) yang direndam air selama 24 jam. Air rendaman ini untuk menyemprot hama. Dari situ lalu menghitung keuntungan bertani organik. Dengan biaya Rp.2,2-2,4 juta per ha, bisa dihasilkan Rp.10 juta per ha dalam empat bulan (sekali masa panen). Perhitungan tadi memakai asumsi tiap hektare sawah menghasilkan padi gabah kering panen 7 ton dengan harga Rp.1.450 per kg jenis menthik (Jarot, 2007).

Pengertian Padi Organik. Padi organik adalah padi yang disahkan oleh sebuah badan independen, untuk ditanam dan diolah menurut standar organik yang ditetapkan. Walau tidak ada satu definisi pun untuk organik, 
kebanyakan definisi memiliki elemen umum. Misalnya, organik sebagaimana digunakan pada kebanyakan tanaman sawah yang umumnya berarti bahwa: (1) Tidak ada pestisida dan pupuk dari bahan kimia sintetis atau buatan yang telah digunakan, (2) Kesuburan tanah dipelihara melalui proses alami seperti penanaman tumbuhan penutup atau penggunaan pupuk kandang yang di kompos dan limbah tumbuhan, (3) Tanaman dirotasikan di sawah untuk menghindari penanaman tanaman yang sama dari tahun ke tahun di sawah yang sama, (4) Pergantian bentuk-bentuk bukan kimia dari pengendalian hama. (Bawolye dan Syam, 2006).

Produk organik terutama di pasar-pasar maju biasanya menerima harga yang lebih tinggi. Produk organik juga sering dianggap sebagai memiliki manfaat kesehatan yang lebih besar. Sebagaimana yang terlibat dalam penanaman padi organik adalah: (1) Harus mengikuti standar ketat untuk produksi dan pengolahan yang ditetapkan oleh badan sertifikasi, (2) Harus membuat dan menyerahkan rencana tahunan yang memperlihatkan bahwa memenuhi persyaratan produksi dan pengolahan dari badan sertifikasi, (3) Produk hanya dapat disertifikasi organik bila produk ditanam di lahan yang telah bebas dari zat-zat terlarang (misalnya, pestisida dan pupuk kimia buatan) selama tiga tahun sebelum sertifikasi, (4) Tantangan utama dari penanaman padi awalnya berkaitan dengan pengelolaan hara dan pengendalian gulma. Contoh utama mencakup: (a) Nitrogen biasanya disediakan melalui penanaman leguminosa penutup tanah, (b) Pupuk dari tulang merupakan sumber fosfor murah yang baik (dengan kadar sekitar 12 persen). Hal ini cepat berfungsi dan berlangsung sampai 6 bulan. Sumber lain adalah dari Rock Phos- phate, yang memiliki rasio 33 persen. Dengan Rock Phosphate hanya akan mendapatkan sekitar 10 persen pada tahun pertama karena lamban fungsinya dan berlangsung selama 3-5 tahun, (c) Jerami dan pupuk kandang merupakan sumber kalium yang baik. Kalium dapat berkadar tinggi dalam air irigasi, (d) Gulma dapat dikurangi melalui perataan lahan yang baik, pengelolaan air, pengolahan tanah, dan rotasi tanaman, (e) Sebagian besar serangga dan penyakit dapat dikendalikan melalui penggunaan varietas yang tepat, (5) Harus membuat catatan terperinci mengenai metode dan bahan yang digunakan dalam penanaman atau pengolahan produk organik untuk memperlihatkan bahwa standar telah dijaga dan diperiksa, (6) Membutuhkan pihak ketiga yang disetujui oleh badan sertifikasi nasional untuk mensertifikasi yang setiap tahun menginspeksi semua metode dan bahan. (Bawolye dan Syam, 2006).

Fungsi Produksi Padi Organik. Fungsi produksi padi organik pada dasarnya adalah meniadakan atau membatasi keburukan budidaya kimiawi dan resiko yang ditimbulkannya. Hal itu mencakup: (1) Menghemat penggunaan hara tanah, berarti memperpanjang umur produktif tanah, (2) Melindungi tanah terhadap kerusakan karena erosi dan mencegah degradasi tanah karena kerusakan struktur pemampatan, (3) Menghindari terjadinya ketimpangan hara dalam tanah, bahkan dapat memperbaiki neraca hara dalam tanah, (4) Memperbaiki penyediaan lengas tanah, sehingga membatasi resiko kekeringan pada pertanaman dan memperbaiki ketersediaan hara tanah dan hara pupuk mineral, berarti meningkatkan efisiensi penggunaannya dan menghemat penggunaan pupuk buatan yang mahal, (5) Melindungi pertanaman terhadap 
cekaman oleh unsur-unsur yang ada dalam tanah $(\mathrm{Al}, \mathrm{Fe}, \mathrm{Mn})$ atau yang masuk ke dalam tanah dari bahan-bahan pencemar logamlogam berat, (6) Tidak membahayakan kehidupan flora dan fauna tanah, bahkan dapat menyehatkanya, berarti memelihara ekosistem tanah, (7) Tidak menimbulkan pencemaran lingkungan, khususnya atas bekalanbekalan air, kerena zat-zat kimia yang di kandungnya berkadar rendah dan berbentuk senyawa yang tidak mudah larut, (8) Berharga murah kerena pupuk organik terutama dihasilkan dari bahan-bahan yang tersediakan di dalam usahatani sendiri dan pupuk hayati hanya diperlukan dalam jumlah sedikit, sehingga menekan biaya produksi usahatani, dan (9) Merupakan teknologi berkemampuan ganda, sehingga cocok sekali untuk diterapkan pada tanah-tanah yang berpersoalan ganda yang terdapat luas sekali di Indonesia (tanah acrisol, nitosol, ferralsol).

Pengujian di Filipina menunjukkan bahwa pemberian kompos yang dibuat dengan activator Trichoderma dan ditambah hanya dengan setengah takaran pupuk buatan yang biasa diberikan dapat meningkatkan hasil panen sampai 20 persen dibandingkan dengan yang dipupuk dengan takaran penuh pupuk buatan. Vermicompost sudah mulai diproduksi di Indonesia dari sampah kota, antara lain di Semarang. Kegiatan penelitian Jurusan Ilmu Tanah Fakultas Pertanian UGM yang sedang berjalan berkaitan dengan budidaya organik antara lain mencakup pengomposan pangkasan alang-alang dengan activator Trichoderma, pembuatan dan pengujian kompos Azolla untuk ameliorasi lahan kritis, dan pengembangbiakan cacing tanah yang dilepaskan dalam tanah untuk memperbaiki sifat fisik, kimia, dan biologi tanah.

Pupuk organik dan hayati mempunyai berbagai keunggulan nyata dibandingkan dengan pupuk mineral. Pupuk organik dengan sendirinya merupakan keluaran setiap budidaya pertanian, sehingga merupakan sumber hara makro dan mikro yang boleh dikatakan cuma-cuma. Pupuk hayati secara nisbi murah dan diperlukan dalam jumlah sedikit. Dengan pengolahan yang baik, tanah yang pernah dinokalisasi dengan Rhizobium atau mikorosa dan ditanami dengan tanaman yang sama biasanya tidak memerlukan inakulasi ulang. Biakan cacing tanah yang dilepaskan dalam tanah yang sesuai secara ekologi akan berkembang dengan sendirinya. Pupuk organik dan hayati berdaya ameliorasi ganda dengan berbagai proses yang saling mendukung, bekerja menyuburkan tanah dan sekaligus mengkonservasi tanah dan menyehatkan ekosistem tanah serta menghindarkan terjadinya pencemaran lingkungan (Notohadiprawiro, 2006).

Ciri-ciri Padi Organik. Pada umumnya padi organik mempunyai ciri-ciri sebagai berikut:

(1) Tidak ada pestisida dan pupuk dari bahan kimia sintetis atau buatan yang telah digunakan, (2) Kesuburan tanah dipelihara melalui proses alami seperti penanaman tumbuhan penutup atau penggunaan pupuk kandang yang dikompos dan limbah tumbuhan, (3) Tanaman dirotasikan di sawah untuk menghindari penanaman tanaman yang sama dari tahun ke tahun di sawah yang sama, (4) Pergantian bentuk-bentuk bukan kimia dari pengendalian hama digunakan untuk mengendalikan serangga, penyakit dan gulma misalnya serangga yang bermanfaat untuk memangsa hama, jerami setengah busuk untuk menekan gulma, dan lain-lain.

Ciri lain dari padi organik adalah penggunaan pupuk hayati biofertilizers. Pupuk 
hayati ialah sediaan organik yang peran ameliorasinya berasal dari kandungan jasad renik aktif. Pupuk hayati dipilahkan menurut macam hara yang ditanganinya. Salah satu pupuk hayati $\mathrm{N}$ yang sudah dikenal baik di Indonesia ialah inokulum rhizhobium untuk kedelai. Pupuk hayati $\mathrm{N}$ yang lain ialah sediaan jasad renik penghambat $\mathrm{N}$ udara non simbiotik (Azotobacter, Azospirillturn). Pupuk hayati $\mathrm{P}$ ialah sediaan jasad renik pelarut fosfat (Pseudomonas, Bacillus, Aspergillus, Penicillium) yang berguna meningkatkan kadar $\mathrm{P}$ tersediakan dalam tanah atau meningkatkan keterlarutan $\mathrm{P}$ dalam pupuk fosfat alam. Inokulum mikorisa sering juga digolongkan dalam pupuk hayati $\mathrm{P}$ karena dapat melancarkan serapan P oleh tanaman. Sebetulnya peranan mikorisa lebih luas. Mikorisa juga berdaya meningkatkan serapan hara mikro $\mathrm{Zn}$ dan $\mathrm{Cu}$ serta meningkatkan kemampuan tanaman penyerap air. Fungsi ini juga berguna melawan peracunan tanaman oleh unsur-unsur logam berat, antara lain Mn dan Cd. Ada yang memperkirakan mikorisa dapat memperluas sistem perakaran tanaman sampai 1000 kali. Maka mikorisa juga berkemampuan mengurangi kerentanan tanah terhadap erosi (Notohadiprawiro, 2006).

Peranan Bahan Organik terhadap Kesuburan Tanah. Bahan organik di samping berpengaruh terhadap pasokan hara tanah juga tidak kalah pentingnya terhadap sifat fisik, biologi dan kimia tanah lainnya. Syarat tanah sebagai media tumbuh dibutuhkan kondisi fisik dan kimia yang baik. Keadaan fisik tanah yang baik apabila dapat menjamin pertumbuhan akar tanaman dan mampu sebagai tempat aerasi dan lengas tanah, yang semuanya berkaitan dengan peran bahan organik. Peran bahan organik yang paling besar terhadap sifat fisik tanah meliputi: struktur, 6 konsistensi, porositas, daya mengikat air, dan yang tidak kalah penting adalah peningkatan ketahanan terhadap erosi.

Faktor-faktor yang Mempengaruhi Produksi Padi Organik. (1) Lahan basah. Lahan basah adalah istilah kolektif tentang ekosistem yang pembentukanya dikuasai air, dan proses serta cirinya terutama dikendalikan air. Suatu lahan basah adalah suatu tempat yang basah selama waktu cukup panjang bagi pengembangan vegetasi dan organism lain yang teradaptasi khusus. Lahan basah ditakrifkan (define) berdasarkan tiga parameter, yaitu hidrologi, vegetasi hidrofitik, dan tanah hidrik.

Lahan basah mencakup suatu rentangan luas habitat pedalaman, pantai, dan marin yang memiliki sejumlah tampakan sama. Konvensi Ramsar 1971 menakrifkan lahan basah yang penting secara internasional sebagai berikut: Lahan basah adalah rawa, lahan gambut, dan air, baik alami maupun buatan, bersifat sementara, berair ladung (stagnant, static) atau mengalir yang bersifat tawar, payau, atau asin, mencakup wilayah air marin yang di dalamnya pada waktu surut tidak lebih dari enam meter (Notoprawiro, 2006).

(2) Lahan Kering, hingga saat ini takrif pengertian lahan kering di Indonesia belum disepakati benar. Di dalam bahasa Inggris banyak istilah-istilah yang dipadankan dengan lahan kering seperti upland, dryland dan unirrigated land, yang menyiratkan penggunaan pertanian tadah hujan. Istilah upland farming, dryland farming dan rainfed farming dua istilah terakhir yang digunakan untuk pertanian di daerah bercurah hujan terbatas. Pengertian upland mengandung arti lahan atasan yang merupakan lawan kata bawahan (lowland) yang terkait dengan kondisi drainase. Sedangkan istilah unirrigated 
land biasanya digunakan untuk teknik pertanian yang tidak memiliki fasilitas irigasi. Namun pengertian lahan tidak beririgasi tidak memisahkan pengusahaan lahan dengan sistem sawah tadah hujan.

Untuk menghilangkan kerancuan pengertian lahan kering dengan istilah pertanian ada beberapa pengertian sebagai berikut: (a) Untuk kawasan atau daerah yang memiliki jumlah evaporasi potensial melebihi jumlah curah hujan actual atau daerah yang jumlah curah hujannya tidak mencukupi untuk usaha pertanian tanpa irigasi disebut dengan daerah kering, (b) Untuk lahan dengan drainase alamiah lancar dan bukan merupakan daerah dataran banjir, rawa, lahan dengan air tanah dangkal, atau lahan basah alamiah lain istilahnya lahan atasan atau Upland, (c) Untuk lahan pertaian yang diusahakan tanpa penggenangan, istilahnya lahan kering.

Kesepakatan pengertian lahan kering dalam seminar nasional pengembangan wilaah lahan kering ke-3 di Lampung upland dan rainfed adalah hamparan lahan yang didayaunakan tanpa penggenangan air, baik secara permanen maupun musiman dengan sumber air berupa hujan atau air irigasi. Definisi lahan kering adalah hamparan lahan yang tidak pernah tergenang atau digenangi air selama periode sebagian besar waktu dalam setahun. Tipologi lahan ini dapat dijumpai dari dataran rendah $(0-700 \mathrm{~m} \mathrm{dpl})$ hingga dataran tinggi ( $>700 \mathrm{~m} \mathrm{dpl)}$. Dari pengertian di atas, maka jenis penggunaan lahan yang termasuk dalam kelompok lahan kering mencakup: lahan tadah hujan, tegalan, ladang, kebun campuran, perkebunan, hutan, semak, padang rumput, dan padang alang-alang.

Lahan kering mempunyai potensi yang cukup luas untuk dikembangkan, dengan luas yang mencapai 52,5 juta ha untuk seluruh indonesia maka pengembangan sangat perlu dilakukan. Penggunaan lahan untuk lahan kering berturut adalah sebagai berikut: hutan rakyat, perkebunan, tegalan, tanah yang sedang tidak diusahakan, ladang dan padang rumput (La An, 2007).

Benih Padi. Padi merupakan tanaman pangan berupa rumput berumpun. Tanaman pertanian kuno berasal dari dua benua yaitu Asia dan Afrika Barat tropis dan subtropis. Bukti sejarah memperlihatkan bahwa penanaman padi di Zhejiang (Cina) sudah dimulai pada 3.000 tahun SM. Fosil butir padi dan gabah ditemukan di Hastinapur Uttar Pradesh India sekitar 100-800 SM. Selain Cina dan India, beberapa wilayah asal padi adalah, Bangladesh Utara, Burma, Thailand, Laos, Vietnam. Klasifikasi botani tanaman padi adalah sebagai berikut:

Divisi: Spermatophyta, Sub divisi: Angiospermae, Kelas: Monotyledonae, Keluarga: Gramineae (Poaceae), Genus: Oryza, Spesies: Oryza spp.

Terdapat 25 spesies Oryza, yang dikenal adalah $O$. Sativa dengan dua subspecies yaitu Indica (padi bulu) yang ditanam di Indonesia dan Sinica (padi cere). Padi dibedakan dalam dua tipe yaitu padi kering (gogo) yang ditanam di dataran tinggi dan padi sawah di dataran rendah yang memerlukan penggenangan. Varitas unggul nasional berasal dari Bogor: Pelita I/1, Pelita I/2, Adil dan Makmur (dataran tinggi), Gemar, Gati, GH 19, GH 34 dan GH 120 (dataran rendah). Varitas unggul introduksi dari International Rice Research Institute (IRRI) Filipina adalah jenis IR atau PB yaitu IR 22, IR 14, IR 46 dan IR 54 (dataran rendah); PB32, PB 34, PB 36 dan PB 48 (dataran rendah). (Kemal Prihatman, 2000). 
Tenaga Kerja. Tenaga kerja adalah daya manusia untuk melakukan pekerjaan. Pengertian umum tersebut sesuai dengan pengertian tenaga kerja yang dimuat dalam UndangUndang Pokok Ketenagakerjaan No. 14 Tahun 1969, yaitu "Setiap orang yang mampu melakukan pekerjaan baik di dalam maupun di luar hubungan kerja guna menghasilkan jasa atau barang untuk memenuhi kebutuhan masyarakat".

Ananta dan Tjiptoherijanto (1985) menyatakan bahwa tenaga kerja adalah sebagian dari seluruh penduduk yang secara potensial dapat menghasilkan barang dan jasa. Sehingga dari pernyataan tersebut dapat diambil kesimpulan bahwa tenaga kerja adalah sebagian penduduk yang dapat menghasilkan barang dan jasa bila ada permintaan barang dan jasa.

Pada tahun 2000, kesempatan kerja pada sektor pertanian menempati posisi dominan dengan proporsi 45,28 persen dari total kesempatan kerja yang mencapai 89,84 juta orang. Menurut status pekerjaan, kesempatan kerja berburuh (karyawan) mencapai 32,83 persen atau sebesar 29,49 juta orang. Kesempatan kerja berburuh di sektor pertanian mencapai 5,38 juta orang atau 13,23 persen dari total kesempatan kerja sektor pertanian yang besarnya 40,68 juta orang (Badan Pusat Statistik, 2001).

Pupuk. Pupuk organik adalah pupuk yang sebagian besar atau seluruhnya terdiri dari bahan organik yang berasal dari tanaman atau hewan yang telah melalui proses rekayasa, dapat berbentuk padat atau cair yang digunakan untuk mensuplai bahan organik, memperbaiki sifat fisik, kimia, dan biologi tanah. Pupuk organik adalah nama kolektif untuk semua jenis bahan organik asal tanaman dan hewan yang dapat dirombak menja- di hara tersedia bagi tanaman. (Rija, 2007).

Dalam Permentan No. 2/Pert/Hk.060/2/ 2006, tentang pupuk organik dan pembenah tanah, dikemukakan bahwa pupuk organik adalah pupuk yang sebagian besar atau seluruhnya terdiri atas bahan organik yang berasal dari tanaman dan atau hewan yang telah melalui proses rekayasa, dapat berbentuk padat atau cair yang digunakan mensuplai bahan organik untuk memperbaiki sifat fisik, kimia, dan biologi tanah. Definisi tersebut menunjukkan bahwa pupuk organik lebih ditujukan kepada kandungan C-organik atau bahan organik daripada kadar haranya, nilai C-organik itulah yang menjadi pembeda dengan pupuk anorganik. Bila C-organik rendah dan tidak masuk dalam ketentuan pupuk organik maka diklasifikasikan sebagai pembenah tanah organik. Pembenah tanah atau soil ameliorant menurut SK Mentan adalah bahan-bahan sintesis atau alami, organik atau mineral. Sumber bahan organik dapat berupa kompos, pupuk hijau, pupuk kandang, sisa panen (jerami, brangkasan, tongkol jagung, bagas tebu, dan sabut kelapa), limbah ternak, limbah industri yang menggunakan bahan pertanian, dan limbah kota. Kompos merupakan produk pembusukan dari limbah tanaman dan hewan hasil perombakan oleh fungi, aktinomiset, dan cacing tanah. Pupuk hijau merupakan keseluruhan tanaman hijau maupun hanya bagian dari tanaman seperti sisa batang dan tunggul akar setelah bagian atas tanaman yang hijau digunakan sebagai pakan ternak. Sebagai contoh pupuk hijau ini adalah sisa-sisa tanaman, kacang-kacangan, dan tanaman paku air Azolla. Pupuk kandang merupakan kotoran ternak. Limbah ternak merupakan limbah dari rumah potong berupa tulang-tulang, darah, dan sebagainya. Limbah industri yang menggunakan bahan perta- 
nian merupakan limbah berasal dari limbah pabrik gula, limbah pengolahan kelapa sawit, penggilingan padi, limbah bumbu masak, dan sebagainya. Limbah kota yang dapat menjadi kompos berupa sampah kota yang berasal dari tanaman, setelah dipisah dari bahanbahan yang tidak dapat dirombak misalnya plastik, kertas, botol, dan kertas. (Simanungkalit, 2006)

Air. Air dapat berwujud padatan (es), cairan (air) dan gas (uap air). Air merupakan satu-satunya zat yang secara alami terdapat di permukaan bumi dalam ketiga wujudnya tersebut. Pengaturan air yang kurang baik dapat menyebakan kekurangan air, monopolisasi serta privatisasi dan bahkan menyulut konflik. Air adalah substansi kimia dengan rumus kimia $\mathrm{H}_{2} \mathrm{O}$ : satu molekul air tersusun atas dua atom hidrogen yang terikat secara kovalen pada satu atom oksigen. Air bersifat tidak berwarna, tidak berasa dan tidak berbau pada kondisi standar, yaitu pada tekanan 100 $\mathrm{kPa}(1 \mathrm{bar})$ and temperatur $273,15 \mathrm{~K}\left(0^{\circ} \mathrm{C}\right)$. Zat kimia ini merupakan suatu pelarut yang penting, yang memiliki kemampuan untuk melarutkan banyak zat kimia lainnya, seperti garam-garam, gula, asam, beberapa jenis gas, dan banyak macam molekul organik.

Air merupakan salah satu sumber daya alam yang sangat esensial bagi sistem produksi pertanian. Air bagi pertanian tidak hanya berkaitan dengan aspek produksi, melainkan juga sangat menentukan potensi perluasan areal tanam ekstensifikasi, luas areal tanam, intensitas pertanaman, serta kualitas hasil.

Pemberian air pada lahan sawah telah menjadi prioritas pembangunan pertanian selama beberapa pelita, namun pengairan pada lahan kering belum banyak diapdosi petani Indonesia atau mendapat perhatian dari pemerintah. Petani lahan kering biasanya mengandalkan curah hujan untuk mengairi lahan usaha taninya, karena untuk keperluan itu hamper tidak memerlukan biaya. Pada bulan-bulan tidak ada hujan atau kemarau, lahan pertanian sering kali diberakan. Akibatnya indeks pertanaman lahan kering relative rendah, baru mencapai 0,50-1 (Kurnia, 2004).

Penelitian Terdahulu. Penelitian yang dilakukan oleh Hermaya Rukka, Buhaerah dan Sunaryo Tahun 2006 yang berjudul "Hubungan Karakteristik Petani dengan Respon Petani terhadap Penggunaan Pupuk Organik Pada Padi Sawah (Oryza Sativa)". Dalam penelitian tersebut data yang dipergunakan adalah data yang diperoleh dari hasil survai dan wawancara langsung dengan petani dengan menggunakan kuesioner yang berkaitan dengan masalah yang diteliti. Hasil dari penelitian ini adalah Respon petani berpengaruh terhadap penggunaan pupuk organik khususnya bokashi pada padi sawah dan Faktor internal yang berpengaruh pada respon petani terhadap penggunaan pupuk organik pada padi sawah seperti motivasi petani, pengalaman berusaha tani dan luas lahan garapan, sedang pada tingkat pendidikan formal tidak memperlihatkan adanya kolerasi atau hubungan dengan respon petani. Faktor eksternal yang berpengaruh pada respon petani terhadap penggunaan pupuk organik pada padi sawah yaitu sarana dan prasarana. Sebaliknya pada intensitas penyuluhan dan peluang pasar tidak menunjukkan adanya korelasi atau hubungan dengan respon petani.

Penelitian yang dilakukan oleh Dewi Sahara dan Idris tahun 2005 yang berjudul "Efisiensi Produksi Sistem Usahatani Padi pada Lahan Sawah Irigasi Teknis". Dalam penelitian tersebut data yang digunakan 
meliputi data primer dan data sekunder. Data primer diperoleh melalui wawancara dengan 30 petani padi sawah yang dipilih secara acak sederhana. Pengamatan dilakukan terhadap karakteristik petani dan penggunaan sarana produksi usahatani tani. Karakteristik petani meliputi data umur petani, pendidikan, tanggungan keluarga dan pengalaman berusahatani, sedangkan sarana produksi usahatani meliputi penggunaan benih, pupuk, pestisida, tenaga kerja, biaya usahatani, produktivitas tanaman, dan harga produksi. Hasil dari penelitian ini adalah Secara teknis faktor-faktor yang mempengaruhi produksi padi sawah adalah luas panen, pestisida dan tenaga kerja. Ketiga faktor produksi tersebut masih bisa dinaikkan jumlahnya untuk meningkatkan produksi. Secara ekonomis efisiensi produksi dalam usahatani padi di lahan sawah irigasi belum optimal. Pencapaian efisien masih dimungkinkan dengan mengurangi penggunaan pupuk SP-36 untuk menambah pendapatan.

Penelitian yang dilakukan oleh Joko Pramono Tahun 2001 yang berjudul "Kajian Penggunaan Bahan Organik pada Padi Sawah". Dalam penelitian tersebut data yang digunakan dengan Metode penelitian menggunakan rancangan percobaan Acak Kelompok (RCBD), dengan 5 perlakuan dan ulangan sebanyak 4 kali. Hasil dari penelitian ini adalah Hasil analisis statistik terhadap parameter pertumbuhan tanaman dan komponen hasil padi sawah menunjukkan bahwa terdapat perbedaan yang nyata antara perlakuan pemberian bahan organik dibandingkan dengan pola petani sebagai kontrol. Pada peubah panjang malai dan jumlah malai per meter persegi menunjukkan adanya perbedaan antara perlakuan penambahan pupuk Mekanik dengan kontrol.

\section{METODE PENELITIAN}

\section{Jenis dan Sumber Data}

Penelitian ini menggunakan data primer. Data primer adalah data yang diperoleh secara langsung dari sumber data yang masih berkaitan dengan data tersebut. Data primer tersebut meliputi tentang hasil produksi padi, luas lahan garapan, air, benih padi, dan tenaga kerja yang digunakan.

Data tersebut menggunakan data primer dengan menggunakan metode sampling dan ukuran sample. Penentuan sampling dilakukan secara purposive sampling yang terkuota, yaitu memilih daerah yang mempunyai pengairan yang mencukupi. Jumlah sampel yang di ambil terkuota untuk memenuhi kriteria sampel kecil, sehingga diambil sebanyak 30 petani.

\section{Definisi Operasional Variabel}

Dalam penelitian ini variabel yang digunakan adalah sebagai berikut:

(1) Produksi Padi Organik. Produksi Padi Organik adalah hasil jumlah usaha yang dilakukan oleh para petani padi organik untuk memperoleh hasil produksi padi organik yang sebanyak-banyaknya yang dinyatakan dengan satuan ton.

(2) Luas Tanah. Luas Tanah adalah jumlah luas lahan atau sawah yang dimiliki oleh para petani organik untuk menanam padi organik yang dinyatakan dengan satuan $\mathrm{m}^{2}$.

(3) Benih Padi. Benih Padi adalah tanaman pangan berupa rumput berumpun yang digunakan oleh para petani untuk menanam padi organik yang dinyatakan dengan satuan $\mathrm{kg}$.

(4) Tenaga Kerja. Tenaga Kerja adalah para petani organik yang bekerja di sawah untuk menghasilkan suatu produksi padi organik 
setiap kenaikan penggunaan air sebesar 1 persen maka produksi beras organik meningkat sebesar 0,232 persen, dengan tingkat signifikan sampai dengan 90 persen. Hal ini terjadi karena peningkatan penggunaan air yang digunakan untuk mengairi tanaman padi akan menambah jumlah kepadatan butiran padi pada saat padi mulai berbuah sehingga butiran padi menjadi lebih berat dan berisi sehingga produksi padi menjadi meningkat.

\section{KESIMPULAN}

Dari hasil analisis di atas, dapat disimpulkan bahwa:

Pertama, model yang digunakan terbebas dari masalah asumsi klasik, baik multikolinearitas, heteroskedastisitas, autokorelasi, spesifikasi model, dan normalitas.

Kedua, berdasarkan hasil olahan data dapat dijelaskan bahwa terdapat hubungan yang signifikan antara variabel Luas Lahan (LH), Jumlah Benih (BH), Jumlah Tenaga Kerja (TK), Jumlah Pupuk (PPK) dan Biaya Pengairan (AIR) dengan produksi beras organik, Namun dari kelima variabel tersebut variabel pupuk berhubungan secara negatif. Sedangkan uji eksistensi model menunjukkan bahwa model Eksis untuk digunakan dengan nilai variasi sebesar 68,9 persen.

Ketiga, Luas lahan (LH) memiliki pengaruh positif terhadap produksi beras organik dengan tingkat koefisien sebesar 0,290, Jumlah benih (BH) memiliki pengaruh positif terhadap produksi beras organik dengan tingkat koefisien sebesar 0,277, Tenaga kerja (TK) memiliki pengaruh positif terhadap produksi beras organik dengan tingkat koefisien sebesar 0,371, Penggunaan pupuk organik (PPK) memiliki pengaruh nagatif terhadap produksi beras organik dengan tingkat koefisien sebesar 0,246. Biaya pengairan (AIR) memiliki pengaruh positif terhadap produksi beras organik dengan tingkat koefisien sebesar 0,232. Dari kelima variabel tersebut memiliki tingkat signifikansi sampai dengan 90 persen.

Berdasarkan pada hasil kesimpulan dalam penelitian ini penulis akan sedikit memberi saran, yaitu saran kebijakan untuk meningkatkan produksi beras organik. Namun perlu dicermati kebijakan tersebut harus didukung dengan beberapa rekomendasi kebijakan lain yang dapat ditempuh antara lain adalah: (1) Karena luas lahan, benih, air dan tenaga kerja memiliki pengaruh positif terhadap produksi beras organik. Maka diharapkan Dinas Pertanian Sragen memperhatikan hal-hal tersebut untuk meningkatkan produksi padi organik di waktu yang akan datang, (2) Pemerintah seyogyanya dapat menjamin bahwa hasil pertanian organik dapat dijual di pasar dengan harga yang relatif tinggi sehingga petani mendapat harga gabah/padi sebesar harga pemerintah, sehingga produksi dapat dimaksimalkan, (3) Instansi terkait, khususnya Bulog/Dolog, dapat langsung membeli gabah dari petani sehingga memotong rantai perdagangan. (4) Perlu adanya penelitian lanjutan dari penelitian ini karena penelitian ini belumlah sempurna karena keterbatasan pengetahuan dan waktu dari peneliti.

\section{DAFTAR PUSTAKA}

Ananta, Aris dan Prijono Tjiptoherijanto. 1985. Masalah Penyerapan Tenaga Kerja. Jakarta: Sinar Harapan.

Arafah. 2003. Kajian penggunaan jerami dan pupuk N, P dan K pada Lahan Sawah Irigasi. Ilmu Tanah dan Lingkungan, 4 (1):15-24 
Arief, Sritua. 1993. Metodologi Penelitian Ekonomi. Jakarta: UI press.

Bawolye, J. dan M. Syam. 2006. Padi Orga$n i k$, (http://balitpa.litbang.deptan.go. id; diakses tanggal 4 April 2006).

BPS kabupaten Sragen. 2006. Sragen dalam angka: BPS Sragen

Gujarati, Damodar. 1995. Ekonometrika Dasar Alih bahasa Sumarno Zain. Jakarta: Airlangga

Gujarati, Damodar. 1999. Ekonometrika Dasar Alih bahasa Sumarno Zain. Jakarta: Airlangga.

Hermaya Rukka, dkk. 2006. Hubungan Karakteristik Petani dengan Respon Petani terhadap Penggunaan Pupuk Organik pada Padi Sawah (Oryza Sativa). Agrisistem. 2 (1)

Iqbal, Achmad. 2008. Potensi Kompos dan Pupuk Kandang untuk Produksi Padi Organik. Akta Agrosia, 1(1):13-18

Jarot. 2007. Sragen Ingin Jadi Sentra Produksi Beras Organik, (http://www.tempointeraktif.com, diakses tanggal 24 juli 2007).

Kurnia, Undang. 2004. Prospek pengairan Pertanian Tanaman Semusim Lahan Kering. Bogor: Balai Penelitian Tanah.

La An, 2007. "Lahan Kering". (http://216. 239.33.100/search?q:rudyct.tripod.com/ sem1_023/umi_haryti.htm+lahan+kerin g\&hl. Diambil pada tanggal 30 Maret 2009).

Notohadiprawiro, Tejoyuwono. 2006. Budidaya Organik. Ilmu Tanah Universitas Gadjah Mada, 1(1): 1-5.
Notohadiprawiro, Tejoyuwono. 2006. Lahan Basah, Ilmu Tanah Universitas Gajah Mada 2(1): 1.

Pramono, Joko. 2001. Kajian Penggunaan Bahan Organik pada Padi Sawah. Ungaran: Balai Pengkajian Teknologi Pertanian.

Prihatman, Kemal. 2000. Padi, Budidaya Pertanian, 1(1):1-16.

Sahara, Dewi dkk. 2005. Efisiensi Produksi Sistem Usahatani Padi Pada Lahan Sawah Irigasi Teknis. Sulawesi Tenggara: Balai Pengkajian Teknologi Pertanian.

Simanungkalit. 2006. Pupuk Organik dan Pupuk Hayati. Bogor: Balai Besar Penelitian dan Pengembangan Sumberdaya Lahan Pertanian.

Soekartawi. 1994. Teory Ekonomi Produksi. Jakarta: PT. Raja Grafindo Persada.

Sudirja, Rija. 2007. Standart Mutu Pupuk Organik dan Pembenahan Tanah. Modul Pelatihan Pembuatan Kompos. Lembang.

Sumardi. 2007. Respon Padi Sawah pada Teknik Budidaya Secara Aerobic dan Pemberian Bahan Organik. Akta Agrosia, 1(1):65-71.

Susilowati, Indah. 2004. Analisis Efisiensi Usaha Tani pada Usaha Tani Padi pada Lahan Sempit dengan Irigasi Tadah Hujan. Analisis Efisiensi, 1(1):1-16 


\title{
PEDOMAN PENULISAN \\ JURNAL EKONOMI PEMBANGUNAN FAKULTAS EKONOMI UNIVERSITAS MUHAMMADIYAH SURAKARTA
}

Terbit: 2 kali dalam setahun pada bulan Juni dan Desember

\author{
Akreditasi Jurnal: \\ KEPUTUSAN DIREKTUR JENDERAL PENDIDIKAN TINGGI \\ KEMENTERIAN PENDIDIKAN NASIONAL NOMOR: 51/DIKTI/Kep./2010 \\ (masa berlaku Juni 2010 s.d Juni 2013)
}

1. Artikel ditulis dengan bahasa Indonesia atau bahasa Inggris dalam bidang kajian masalah ekonomi dan pembangunan.

2. Substansi artikel diharapkan sejalan dengan Panduan Akreditasi Berkala Ilmiah 2006, yang diterbitkan Direktorat Penelitian dan Pengabdian kepada Masyarakat (DP2M) Direktorat Jenderal Pendidikan Tinggi Republik Indonesia).

3. Artikel ditulis dengan kaidah tata bahasa Inggris ataupun bahasa Indonesia yang baik dan benar.

4. Sistematika Penulisan

Sistematika penjenjangan atau peringkat judul artikel dan bagian-bagiannya dilakukan dengan cara berikut:

(1) Judul ditulis dengan huruf besar semua, di bagian tengah atas pada halaman pertama

(2) Sub Bab Peringkat 1 ditulis dengan huruf pertama besar semua di tengah/center

(3) Sub Bab Peringkat 2 ditulis dengan huruf besar-kecil rata tepi kiri

- Sistematika artikel hasil penelitian adalah: judul; nama penulis (tanpa gelar akademik); nama dan alamat institusi, alamat e-mail penulis, abstrak (maksimum 150 kata) yang berisi tujuan, metode, dan hasil penelitian; kata kunci (4-5 kata kunci); pendahuluan (tanpa ada subjudul) yang berisi latar belakang, sedikit tinjauan pustaka, dan tujuan penelitian; metode; hasil penelitian dan pembahasan; kesimpulan; daftar rujukan (hanya memuat sumber-sumber yang dirujuk).

\section{JUDUL UTAMA:}

\section{Sub Judul}

Penulis $1^{1}$ dan Penulis $2^{2}$

${ }^{1}$ Nama instansi/lembaga Penulis 1

Alamat lengkap instansi penulis, nomor telepon instansi penulis

${ }^{2}$ Nama instansi/lembaga Penulis 2

Alamat lengkap instansi penulis, nomor telepon instansi penulis

(jika nama instansi penulis 1 dan 2 sama, cukup ditulis satu saja)

E-mail penulis 1 dan 2:

Abstrak: Abstrak dalam bahasa Indonesia (125 - 150 kata)

Kata kunci: 4 - 5 katal frase

Abstract: Abstract in english (125 - 150 words)

Keywords: $4-5$ words/ phrase

\section{PENDAHULUAN}

(berisi latar belakang, sekilas tinjauan pustaka, dan tujuan penelitian, yang dimasukkan dalam paragraf paragraf bukan dalam bentuk subbab)

METODE PENELITIAN

Subbab

Subbab

...

\section{HASIL ANALISIS DAN PEMBAHASAN}

Pedoman Penulisan Jurnal Ekonomi Pembangunan FE Universitas Muhammadiyah Surakarta 


\title{
Subbab
}

\section{KESIMPULAN \\ DAFTAR PUSTAKA}

- Sistematika artikel hasil pemikiran adalah: judul; nama penulis (tanpa gelar akademik); nama dan alamat institusi, alamat e-mail penulis, abstrak (maksimum 150 kata); kata-kata kunci (4-5 kata kunci); pendahuluan (tanpa ada subjudul) yang berisi latar belakang dan tujuan atau ruang lingkup tulisan; bahasan utama (dapat dibagi ke dalam beberapa sub-judul); penutup atau kesimpulan; daftar rujukan (hanya memuat sumber-sumber yang dirujuk).

\section{JUDUL UTAMA: \\ Sub Judul}

Penulis $1^{1}$ dan Penulis $2^{2}$

${ }^{1}$ Nama instansi/lembaga Penulis 1

Alamat lengkap instansi penulis, nomor telepon instansi penulis

${ }^{2}$ Nama instansi/lembaga Penulis 2

Alamat lengkap instansi penulis, nomor telepon instansi penulis

(jika nama instansi penulis 1 dan 2 sama, cukup ditulis satu saja)

E-mail penulis 1 dan 2 :

\author{
Abstrak: Abstrak dalam bahasa Indonesia (125--150 kata) \\ Kata kunci: 4 - 5 katal frase \\ Abstract: Abstract in english (125 - 150 words) \\ Keywords: $4-5$ words/ phrase

\section{PENDAHULUAN PEMBAHASAN \\ KESIMPULAN} \\ DAFTAR PUSTAKA
}

5. Artikel diketik pada kertas kwarto berkualitas baik. Dibuat sesingkat mungkin sesuai dengan subyek dan metode penelitian (bila naskah tersebut ringkasan penelitian), biasanya 20-25 halaman dengan spasi satu, untuk kutipan paragraf langsung diindent (tidak termasuk daftar pustaka).

6. Marjin atas, bawah, dan samping harus dibuat paling tidak satu inci.

7. Abstrak, ditulis satu paragraf sebelum isi naskah. Abstrak dalam dua bahasa yaitu bahasa Indonesia dan bahasa Inggris. Abstrak tidak memuat uraian matematis, dan mencakup esensi utuh penelitian, metode dan pentingnya temuan dan saran atau kontribusi penelitian.

8. $\quad$ a. Penulisan numbering diintegrasikan dalam paragraf, contohnya:

Tujuan dilakukannya penelitian ini adalah: (1) Untuk mengetahui apakah CSR berpengaruh positif terhadap nilai perusahaan, (2) Untuk mengetahui apakah persentase kepemilikan manajemen berperan sebagai variabel moderating dalam hubungan antara CSR dengan nilai perusahaan, dan (3) Untuk mengetahui apakah tipe industri berperan sebagai variabel moderating dalam hubungan antara CSR dengan nilai perusahaan?

b. Penulisan bullet juga diintegrasikan dalam paragraf dengan menggunakan tanda koma pada antarkata/kalimat tanpa bullet.

9. Tabel dan gambar, untuk tabel dan gambar (grafik) sebagai lampiran dicantumkan pada halaman sesudah teks. Sedangkan tabel atau gambar baik di dalam naskah maupun bukan harus diberi nomor urut.

- Tabel atau gambar harus disertai judul. Judul tabel diletakkan di atas tabel sedangkan judul gambar diletakkan di bawah gambar.

Pedoman Penulisan Jurnal Ekonomi Pembangunan FE Universitas Muhammadiyah Surakarta 
- Sumber acuan tabel atau gambar dicantumkan di bawah tabel atau gambar.

- Garis tabel yang dimunculkan hanya pada bagian header dan garis bagian paling bawah tabel sedangkan untuk garis-garis vertikal pemisah kolom tidak dimunculkan.

Contoh: Tabel

Tabel 1. Bentuk-bentuk Mobilitas Penduduk

\begin{tabular}{llll}
\hline No & Bentuk Mobilitas & Batas Wilayah & Batas Waktu \\
\hline 1. & Ulang-alik (commuting) & Dukuh (dusun) & 6 jam atau lebih dan kembali pada hari yang sama \\
2. & Menginap/mondok di daerah tujuan & Dukuh (dusun) & Lebih dari satu hari tetapi kurang dari 6 bulan \\
3. & Permanen/menetap di daerah tujuan & Dukuh (dusun) & 6 bulan atau lebih menetap di daerah tujuan \\
\hline
\end{tabular}

Sumber: Ida Bagoes, 2000

\section{Contoh: Gambar}

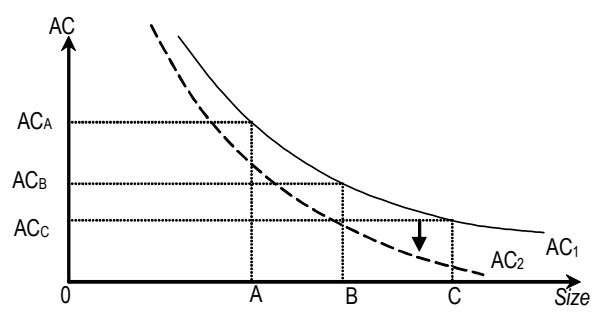

Sumber: Saunders (1997: 291)

Gambar 2. Dampak Peningkatan Teknologi

10. Cara penulisan rumus, Persamaan-persamaan yang digunakan disusun pada baris terpisah dan diberi nomor secara berurutan dalam parentheses (justify) dan diletakkan pada margin kanan sejajar dengan baris tersebut. Contoh:

$\mathrm{wt}=\mathrm{f}\left(\mathrm{y}_{\mathrm{t}}, \mathrm{k}_{\mathrm{t}}, \mathrm{w}_{\mathrm{t}-1}\right)$

11. Keterangan Rumus ditulis dalam satu paragraf tanpa menggunakan simbol sama dengan (=), masingmasing keterangan notasi rumus dipisahkan dengan koma. Contoh:

Dimana $\mathbf{w}$ adalah upah nominal, $\mathbf{y t}$ adalah produktivitas pekerja, kt adalah intensitas modal, $\mathbf{w}_{\mathbf{t}-\mathbf{1}}$ adalah tingkat upah periode sebelumnya.

12. Perujukan sumber acuan di dalam teks dengan menggunakan nama akhir dan tahun. Kemudian bila merujuk pada halaman tertentu, penyebutan halaman setelah penyebutan tahun dengan dipisah titik dua. Untuk karya terjemahan dilakukan dengan cara menyebutkan nama pengarang aslinya.

Contoh:

- Yuni (2008: 23) memandang bahwa .....

- Fatimah dan Daryono (1997) menunjukkan adanya ....

- Didit dkk (2007) berkesimpulan bahwa....

- Untuk meningkatkan perekonomi daerah .... (Yuni, Triyono, dan Agung Riyardi, 2009).

- Maya (2009) berpendapat bahwa ....

13. Setiap kutipan, baik langsung maupun tidak langsung, harus diikuti sumbernya (lihat poin no. 10) dan dicantumkan juga dalam daftar pustaka. Contoh:

Di dalam paragraf isi tercantum kutipan dari: Buiter (2007:15) berpendapat bahwa...

Maka dalam daftar pustaka harus ada sumber referensinya seperti berikut:

Buiter, W. H., (2002). The Fiscal Theory of the Price Level: A Critique, Economic Journal, 112(127): 459-480.

Pedoman Penulisan Jurnal Ekonomi Pembangunan FE Universitas Muhammadiyah Surakarta 
14. Sedapat mungkin pustaka-pustaka yang dijadikan rujukan adalah pustaka yang diterbitkan 10 tahun terakhir dan diutamakan dari jurnal ilmiah.

15. Unsur yang ditulis dalam daftar pustaka secara berturut-turut meliputi: (1) nama akhir pengarang, nama awal, nama tengah, tanpa gelar akademik, (2) tahun penerbitan, (3) judul termasuk subjudul, (4) tempat penerbitan, (5) nama penerbit.

Contoh cara penulisan:

a. Format rujukan dari buku: Nama pengarang, (tahun), Judul Buku, edisi, Kota penerbit, Nama penerbit. Jika penulis sebagai editor tunggal, ditulis (Ed.) di belakang namanya. Ditulis (Eds.) jika editornya lebih dari satu orang. Kemudian bila pengarang lebih dari tiga orang, dituliskan nama pengarang pertama dan yang lain disingkat 'dkk' (pengarang domestik) atau 'et.al.' (pengarang asing).

Enders, W., (2004), Applied Econometric Time Series, Second edition, New York: John Wiley \& Sony Inc. Purnomo, Didit (Ed.). (2005). The Role of Macroeconomic Factors in Growth. Surakarta: Penerbit Muhamadiyah University Press.

b. Format rujukan dari artikel dalam buku ditulis: Nama editor (Ed.), (tahun), Judul tulisan/karangan. Judul buku, hlm atau pp., kota penerbit: nama penerbit

Daryono (Ed.). (2005). Concept of Fiscal Decentralization and Worldwide Overview (hlm. 12-25). Surakarta: Penerbit Muhammadiyah University Press.

c. Format rujukan dari artikel dalam jurnal/majalah/koran: Nama pengarang (tahun). judul tulisan/ karangan. Nama jurnal/majalah/koran, hlm atau pp., volume (nomor), halaman. Jika rujukan koran tanpa penulis, nama koran ditulis diawal.

Rodden, J., (2002). The dilemma of Fiscal Federalism: Grants and Fiscal Performance arround the World. American Journal of Political Science, 46 (3): 670-687.

Triyono (2008). Perimbangan Keuangan Pusat dan Daerah Sebagai Pelaksanaan Desentralisasi Fiskal Efek. Warta Ekonomi, Vol. 4, Agustus: 46-48.

Haryanto, S., (2007, 13 November). Desentralisasi Fiskal dan Pembangunan Ekonomi. Harian Jakarta, hlm.4.

Harian Jogjakarta, (2007, 1 April). Hubungan Keuangan Pusat-Daerah di Indonesia. hlm. 4.

d. Format rujukan dari internet, tanggal akses dicantumkan.

Setyowati, E.,. Keuangan Publik dan Sistem Harga. http://www.ekonomipublik.com/akt/pdf/akt452.pdf.

Diakses tanggal 27 Mei 2009.

\section{Pengiriman Artikel}

1. Artikel dikirimkan sebanyak 2 eksemplar hardcopy, dan softcopy berupa file. File bisa dikirim melalui email jepums@yahoo.co.id atau dalam media cd.

2. Artikel yang dikirim wajib dilampiri biodata ringkas pendidikan termasuk catatan riwayat karya-karya ilmiah sebelumnya yang pernah dipublikasikan, insitusi dan alamatnya, nomor telpon kontak atau e-mail penulis.

3. Penulis yang menyerahkan artikelnya kepada editor atau penerbit, harus menjamin bahwa naskah yang diajukan tidak melanggar hak cipta, belum dipublikasikan atau telah diterima untuk dipublikasi oleh jurnal lainnya.

4. Kepastian pemuatan atau penolakan naskah akan diberitahukan secara tertulis. Penulis yang artikelnya dimuat mendapatkan jurnal tersebut. Artikel yang tidak dimuat tidak akan dikembalikan.

\section{Alamat Redaksi Jurnal Ekonomi Pembangunan Fakultas Ekonomi Universitas Muhammadiyah Surakarta: \\ Redaksi Jurnal Ekonomi Pembangunan Fakultas Ekonomi Universitas Muhammadiyah Surakarta Jalan A. Yani Tromol Pos I Pabelan SURAKARTA 57102 Telp. 0271-717417 psw 229}

Pedoman Penulisan Jurnal Ekonomi Pembangunan FE Universitas Muhammadiyah Surakarta 
TENTANG JURNAL:

\title{
JURNAL EKONOMI PEMBANGUNAN
}

Kajian Masalah Ekonomi dan Pembangunan

ISSN 1411- 6081

\author{
Pimpinan Redaksi \\ Didit Purnomo
}

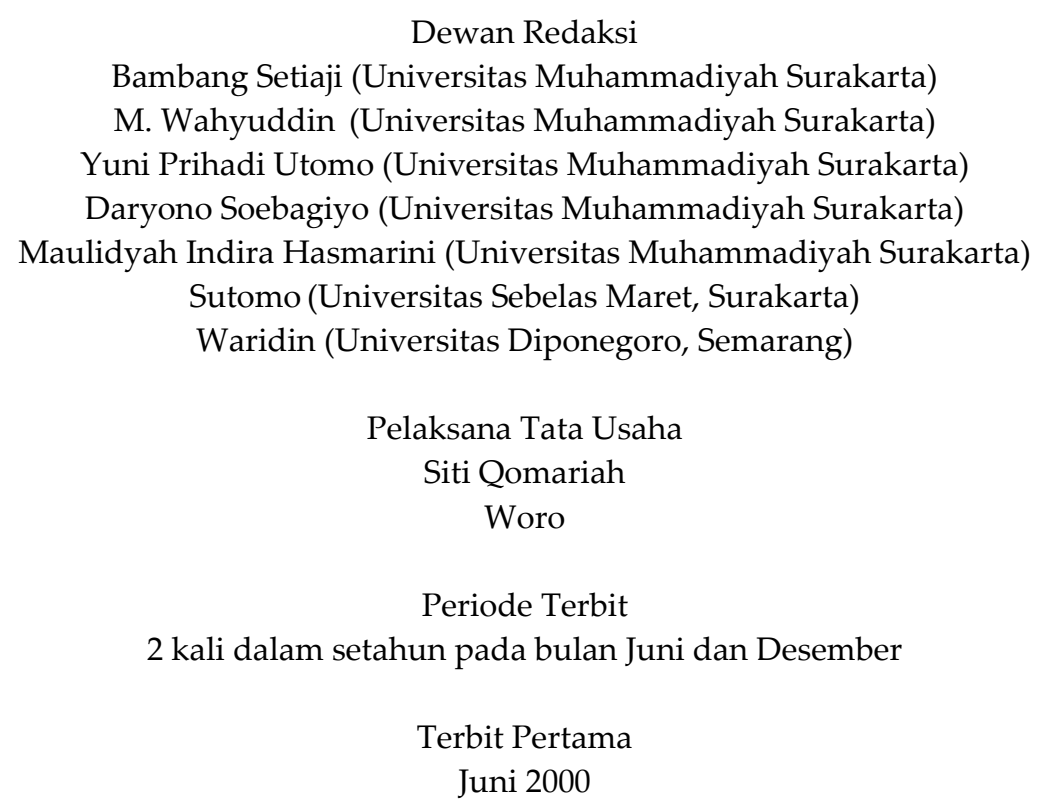

Jurnal EKONOMI PEMBANGUNAN merupakan jurnal ilmiah yang berisikan hasil penelitian dan kajian teoritis mengenai masalah-masalah ekonomi dan pembangunan, khususnya di Indonesia. Diterbitkan oleh Balai Penelitian dan Pengembangan Ekonomi Fakultas Ekonomi Universitas Muhammadiyah Surakarta.

Redaksi menerima sumbangan tulisan yang belum pernah diterbitkan atau dalam proses terbit oleh media lain. Naskah diketik di atas kertas HVS kuarto spasi satu sepanjang lebih kurang 20-25 halaman, dengan format seperti tercantum pada prasyarat naskah jurnal EKONOMI PEMBANGUNAN di halaman belakang. Naskah yang masuk akan dievaluasi dan disunting untuk keseragaman format dan tata cara lainnya.

Alamat Penyunting dan Tata Usaha: Subag Tata Usaha Fakultas Ekonomi Universitas Muhammadiyah Surakarta, Jl. A. Yani, Tromol Pos 1, Pabelan, Surakarta 57102; Telpon (0271) 717417 psw 229,

E-mail: jepums@yahoo.co.id

Website: http://www.ums.ac.id atau http://www.paradejurnal.wordpress.com

Simak informasi jurnal: http://www.paradejurnal.wordpress.com

Admin: Mirat Sidharta. SE

Pedoman Penulisan Jurnal Ekonomi Pembangunan FE Universitas Muhammadiyah Surakarta 